\title{
FAKTOR-FAKTOR YANG MEMPENGARUHI EFEKTIVITAS ORGANISASI SEKRETARIAT KPU KABUPATEN KEPULAUAN MERANTI PADA PEMILU LEGISLATIF TAHUN 2014
}

\author{
M. Arif Almanar 1), Ria Ariany2), Aidinil Zetra ${ }^{3)}$ \\ 1,2,3 ) Magister Konsentrasi Tata Kelola Pemilu Universitas Andalas, Padang, Indonesia
}

\begin{abstract}
Abstrak
Penelitian ini membahas tentang faktor-faktor yang mempengaruhi efektivitas organisasi Sekretariat KPU Kabupaten Kepulauan Meranti pada pelaksanaan tahapan dan kegiatan Pemilu Legislatif Tahun 2014. Penelitian ini dilakukan dengan pendekatan kualitatif dengan tipe penelitian deskriptif. Teori yang digunakan pada penelitian ini adalah teori yang dikemukan oleh Steers tentang faktor-faktor yang mempengaruhi efektivitas organisasi. Hasil penelitian menunjukkan bahwa, situasi pergantian ataupun kekosongan komisioner KPU Kabupaten Kepulauan Meranti pada saat pelaksanaan tahapan dan kegiatan Pemilu Legislatif Tahun 2014 dapat diatasi oleh Sekretariat KPU Kabupaten Kepulauan Meranti dengan memanfaatkan faktor karakteristik organisasi yang solid, karakteristik lingkungan yang kondusif di dalam Sekretariat, karakteristik pekerja yang mempunyai pengalaman dalam dunia organisasi, serta penerapan praktek manajemen organisasi melalui kedekatan secara emosional yang menimbulkan kerja sama dan tanggung jawab didalam organisasi Sekretariat sehingga seluruh tahapan dan kegiatan Pemilu Legislatif Tahun 2014 terlaksana dengan baik sesuai dengan jadwal yang telah ditetapkan.
\end{abstract}

Kata kunci : Efektivitas Organisasi, Sekretariat KPU Kabupaten Kepulauan Meranti, dan Pemilu Legislatif Tahun 2014.

*Correspondence Address : rif.almanar@gmail.com

DOI : 10.31604/jips.v6i2.2019.253-266

(C2019 Fakultas Keguruan \& Ilmu Pendidikan UM-Tapanuli Selatan 


\section{Pendahuluan}

Secara umum, siklus pemilu atau tahapan pemilu merujuk pada sejumlah tahapan pemilu yang dilakukan oleh penyelenggara pemilu seperti perumusan peraturan, registrasi pemilih, pendaftaran dan penetapan partai dan calon, pelaksanaan kampanye, pemungutan dan penghitungan suara, tabulasi hasil penghitungan suara, penetapan dan pengumuman hasil Pemilu, penyelesaian sengketa, pelaporan hasil, dan pengarsipan hasil dan audit manajemen.

Sebagaimana diketahui di dalam struktur internal KPU terdapat dua bagian penting yang menjadi tulang punggung pelaksanaan pemilu, yaitu komisioner atau anggota KPU dan Sekretariat KPU. Kedua bagian tersebut mempunyai struktur berbeda dimana komisioner KPU merupakan pucuk pimpinan lembaga. Keanggotaan komisioner di kabupaten terdiri dari 5 orang anggota independen dengan 1 orang diantaranya menjadi ketua KPU. Masa jabatan komisioner KPU berdasarkan Undang-Undang Nomor 7 Tahun 2017 tentang Pemilihan Umum adalah lima tahun dan diperbaharui atau diseleksi kembali pada saat berakhirnya masa jabatan atau diperbaharui menjelang pemilu. Sedangkan
Sekretariat KPU merupakan bagian penting yang membantu kinerja komisioner untuk mendukung kelancaran tugas dan wewenang KPU yang diisi oleh pegawai organik KPU dan pegawai yang diperbantukan di lembaga KPU.

Di dalam ketentuan perundangundangan diatur bahwa masa kerja anggota Komisioner KPU, KPU Provinsi dan KPU Kabupaten Kota adalah selama lima tahun di hitung sejak di tetapkan, dan hanya dapat dipilih kembali maksimal dua kali masa periode kerja. Kemudian karena waktu penetapan komisoner berbeda-beda di tiap tempat serta ada banyaknya faktor teknis maupun non teknis yang mengakibatkan kemungkinan terjadinya situasi kekosongan komisiner KPU, KPU Provinsi, dan KPU Kabupaten/kota. Hal tersebut akan mengakibatkan terjadinya situasi pergantian ataupun kekosongan komisioner KPU, KPU Prov, dan KPU Kab/Kota pada saat penyelenggaraan tahapan Pemilu sedang berlangsung. Untuk mengatasi pergantian ataupun kekosongan komisioner KPU pada saat Pemilu sedang berlangsung, perlu di tuntut efektifitas organisasi dan kinerja Sekretariat KPU, KPU Provinsi dan KPU Kab./Kota yang merupakan salah satu unsur bagian penyelenggara Pemilu. 
Pada pelaksanaan tahapan dan kegiatan Pemilu Legislatif Tahun 2014 KPU Kabupaten Kepulauan Meranti yang mengalami kekosongan komisioner (5 Anggota KPU Kab). Kronologis terjadinya kekosongan 5 (lima) anggota komisoner KPU Kabupaten Kepulauan Meranti pada saat pelaksanaan tahapan Pemilu sedang berlangsung, karena telah terbitnya keputusan pemberhentian masa kerja komisioner periode 2010-2014 berdasarkan surat keputusan KPU Provinsi Riau pada tanggal 20 Februari 2014.

Berbeda dengan anggota KPU sekabupaten/kota yang berada di Provinsi Riau dimana pasca SK pemberhentian anggota komisioner lama langsung dilantik anggota KPU periode selanjutnya, anggota komisioner KPU Kabupaten Kepulauan Meranti periode selanjutnya 2014-2019 baru resmi ditetapkan dan dilantik pada tanggal 1 April 2014 atau tepatnya 8 (delapan) hari menjelang pemungutan suara Pemilu Legislatif Tahun 2014 yang jatuh pada tanggal 9 April 2014. Artinya pada saat itu terjadi kekosongaan jabatan komisioner di KPU Kabupaten Kepulauan Meranti selama 40 hari dan disaat bersamaan tahapan penyelengaraan Pemilu Legislatif Tahun 2014 tetap harus dilaksanakan yakni tahapan Kampanye dan tahapan Logistik.

Dalam menghadapi situasi pergantian ataupun kekosongan komisioner pada saat pelaksanaan Pemilu Legislatif Tahun 2014, tentunya tergantung pada efektivitas dari organisasi Sekretariat KPU Kabupaten Kepulauan Meranti.

\section{Konsep Teoritis}

Efektivitas organisasi menurut Richard M. Steers (1985) mengenai teori pembinaan organisasi menyatakan bahwa keberhasilan pembinaan organisasi akan mengakibatkan keberhasilan organisasi.

Kemudian konsep yang ditawarkan oleh Dydiet Hardjito (2001) yang mengemukakan bahwa keberhasilan organisasi dalam mencapai tujuannya dipengaruhi oleh komponenkomponen organisasi yang meliputi: struktur, tujuan, manusia, hukum, prosedur pengoperasian yang berlaku, teknologi, lingkungan, kompleksitas, spesialisasi, kewenangan, dan pembagian tugas.

Dari pendapat para ahli tersebut di atas, dalam rangka mencapai efektivitas suatu organisasi sangat dipengaruhi oleh berbagai faktor yang berbeda-beda tergantung pada sifat dan bidang 
kegiatan atau usaha suatu organisasi. Sejalan dengan hal tersebut maka Kimberly dan Rottman (Dalam Gibson, 1995) berpendapat bahwa efektivitas organisasi ditentukan oleh lingkungan, teknologi, pilihan strategi, proses dan kultur.

Dan terkait dengan penilitian yang peneliti lakukan terhadap efektivitas organisasi Sekretariat KPU Kabupaten Kepulauan Meranti pada Pemilu Legislatif Tahun 2014, menurut peneliti teori yang dikemukakan oleh Steers (1985:8) tentang empat faktor yang berpengaruh terhadap efektivitas organisasi, sangat relevan digunakan pada penelitian ini. Faktor-faktor tersebut adalah:

1. Karakteristik Organisasi

Karakteristik organisasi terdiri dari struktur dan teknologi.

2. Karakteristik Lingkungan

Karakteristik lingkungan ini mencakup dua aspek yaitu internal dan eksternal.

3. Karakteristik Pekerja Karakteristik pekerja berhubungan dengan peranan perbedaan individu para pekerja dalam hubungannya dengan efektivitas.

4. Praktek Manajemen Manajer memainkan peranan sentral dalam keberhasilan suatu organisasi melalui perencanaan, koordinasi dan memperlancar kegiatan yang ditujuan ke arah sasaran.

\section{Metode Penelitiaan}

Desain penelitian ini menggunakan pendekatan penelitian kualitatif. Sebagaimana yang disampaikan oleh Sugiyono (2011:9) yang mendefenisikan bahwa pendekatan kualitatif digunakan untuk meneliti pada kondisi objek yang alamiah dimana peneliti adalah instrument kunci, teknik pengumpulan data dilakukan secara triangulasi (gabungan), analisis data bersifat induktif/kualitatif, dan hasil penelitian kualitatif lebih menekankan makna daripada generalisasi.

\section{Jenis Data}

Dalam penelitian ini terdapat dua jenis data yaitu:

1. Data Primer, yaitu sumber data yang diperoleh di lapangan melalui wawancara dengan memilih para informan sesuai dengan kebutuhan penelitian. Data primer biasanya didapat langsung dari informan. Pada penelitian ini yang menjadi informan adalah:

1. Sekretaris, (1 orang)

2. Kepala Sub Bagian Teknis dan Hupmas, (1 orang) 
3. Kepala Sub Bagian Umum, Keungan dan Logistik (1 orang)

4. Staf pendukung dan pelaksana (PNS). (3 orang)

2. Data Sekunder, yaitu sumber data pendukung seperti catatan atau dokumen-dokumen tertulis, studi kepustakaan yang berkaitan dengan

faktor-faktor yang mempengaruhi efektivitas organisasi Sekretariat KPU kabupaten Kepulauan Meranti dalam menyelenggarakan Pemilu Legislatif Tahun 2014 di Kabupaten Kepulauan Meranti.

\section{PEMBAHASAN}

Faktor-faktor Yang Mempengaruhi Efektivitas Organisasi Sekretariat KPU Kabupaten Kepulauan Meranti pada Pemilu Legislatif Tahun 2014:

\section{Karakteristik Organisasi}

Melalui data yang peneliti peroleh selama penelitian, diketahui bahwa struktur organisasi yang dibentuk/dimiliki oleh Sekretatiat KPU Kabupaten Kepulauan Meranti pada Pemilu Legislatif Tahun 2014 lalu terdiri dari 1 (satu) orang sekretaris 4 (empat) orang Kepala Subbagian dan 7 (tujuh) orang staf yang membantu masing- masing subbagian yakni Subbagian Keuangan Umum dan

Dari stuktur organisasi yang di miliki oleh Sekretariat KPU Kabupaten Kepulauan Meranti pada Pemilu Legislatif Tahun 2014, telah mengikuti standar susunan, tata organisasi KPU Kab. Kota yang diatur dalam ketentuan pasal 16 Peraturan Komisi Pemilihan Umum Nomor 6 Tahun 2008 tentang Komisi Pemilihan Umum tentang Susunan Organisasi dan Tata Kerja Sekretariat Jenderal Komisi Pemilihan Umum, Sekretariat Komisi Pemilihan Umum Provinsi, dan Sekretariat Komisi Pemilihan Umum Kabupaten/Kota.

Jika dilihat dari jumlah personil, sebenarnya jumlah pegawai sekretariat KPU Kabupaten Kepulauan Meranti dikategorikan masih kurang ideal dalam rangka menyelenggarakan Pemilu Legislatif Tahun 2014. Mengingat banyaknya tahapan dan kegiatan yang mesti dilaksanakan sesuai dengan jadwal yang telah ditetapkan. Terlebih lagi pada saat pelaksanaan tahapan Pemilu Legislatif Tahun 2014 sedang berlangsung, KPU Kabupaten Kepulauan Meranti mengalami kekosongan komisioner selama 40 hari. Dimana pada waktu kekosongan komisioner tersebut tengah dilaksanakan tahapan kampanye dan tahapan logistik Pemilu. 
Menariknya meski mengalami pergantian dan kekosongan komisioner, Sekretariat KPU Kabupaten Kepulauan Meranti tetap mampu melaksanakan seluruh tahapan dan kegiatan Pemilu Legislatif Tahun 2014 dengan baik sesuai dengan jadwal yang telah ditetapkan.

Keberhasilan tersebut tentunya dipengaruhi oleh karakteristik organisasi yang dimiliki oleh sekretariat KPU Kab. Kepulauan Meranti, yang terbentuk atas aktivitas yang dilakukan dalam lingkungan sekretariat KPU Kab. Kepulauan Meranti. Melalui petikan wawancara yang peneliti lakukan dengan informan, yakni Sekretaris KPU Kabupaten Kepulauan Meranti pada Penyelenggaraan Pemilu Legislatif Tahun 2014 lalu Drs. Zahuri, MM, di peroleh informasi penting bahwa:

Sekretariat KPU Kab. Kepulauan Meranti melakukan rapat rutin dan rapat situasional dalam melaksanakan setiap tahapan dan kegiatan Pemilu Legislatif Tahun 2014.

Kemudian selain kegiatan rapat, dalam rangka meningkatkan disiplin pegawai Sekretariat KPU Kabupaten Kepulauan Meranti pada Pemilu Legislatif Tahun 2014 lalu. Sekretaris selaku pucuk pimpinan organisasi sekretariat, juga menginstruksikan kepada seluruh jajaran sekretariat untuk melakukan apel rutin setiap hari.

Dari data yang penelti peroleh selama penelitian terkait faktor karakteristik organisasi yang menunjang Sekretariat KPU Kabupaten Kepulauan Meranti pada Pelaksanaan Pemilu Legislatif Tahun 2014 sebagaimana tersebut di atas. Dapat disimpulkan bahwa kegiatan rapat rutin dan apel rutin setiap hari yang dilakukan oleh Sekretariat KPU Kabupaten Kepulauan Meranti pada pelaksanaan Tahapan Pemilu Legislatif Tahun 2014 di Kabupaten Kepulauan Meranti merupakan hal penunjang terwujudnya efektivitas organisasi Sekretariat KPU Kabupaten Kepulauan Meranti. Hal positif yang muncul dari rutinitas rapat dan apel pagi tersebut adalah terciptanya organisasi yang solid pada Sekretariat KPU Kab. Kepulauan Meranti pada Pemilu Legislatif Tahun 2014.

\section{Karakateristik Lingkungan}

Karakteristik lingkungan meliputi lingkungan internal dan lingkungan eksternal. Dalam kaitannya dengan penelitian yang peneliti lakukan tentang efektivitas organisasi Sekretariat KPU Kabupaten Kepulauan Meranti pada pelaksanaan tahapan dan kegiatan Pemilu Legislatif Tahun 2014 lalu, 
diperoleh informasi mengenai karakteristik lingkungan sekretariat sebagai berikut:

1. Lingkungan Internal, melalui rangkuman wawancara yang peneliti lakukan dengan informan (Kasubbag dan staf Sekretariat KPU Kab. Kepulauan Meranti), diperoleh fakta bahwa pemanfaatan unsur internal yang berada dalam diri Sekretariat KPU Kabupaten Kepulauan Meranti pada Pemilu Legislatif Tahun 2014 lalu sangat berpengaruh terhadap efektivitas organisasi sekretariat KPU Kabupaten Kepulauan Meranti.

Pemanfaatan unsur internal tersebut meliputi pemanfaatan segala sumber daya yang dimiliki, yakni tenaga (SDM), alat sarana dan prasarana secara maksimal.

Bahwa pada dasarnya pola interaksi di dalam Sekretariat KPU Kabupaten Kepulauan Meranti pada Pemilu Legislatif Tahun 2014 adalah dilandasi semangat sebagai sebuah tim kerja. Hal inilah nampaknya yang menjadi modal dasar keberhasilan efektivitas organisasi Sekretariat KPU Kabupaten Kepulauan Meranti pada Pemilu Legislatif Tahun 2014, yaitu dengan memaksimalkan faktor lingkungan internal yang ada di dalam tubuh Sekretariat KPU Kabupaten Kepulauan Meranti pada Pemilu Legislatif Tahun 2014.

2. Lingkungan eksternal

Dalam kaitannya dengan penelitian ini peneliti menginteprestasikannnya dukungan Panitia Pemilihan Kecamatan (PPK) kepada Sekretariat KPU Kabupaten Kepulauan Meranti pada pelaksanaan tahapan Pemilu Legislatif Tahun 2014 lalu. Khususnya pada saat tahapan logistik, dimana pada tahapan tersebut terjadi kekosongan komisioner KPU Kabupaten Kepulauan Meranti. Dukungan dari PPK menjadi faktor pendukung sehingga segala tantangan dan kendala pada saat pelaksanaan tahapan logistik dapat diatasi dengan baik.

Dari uraian mengenai pengaruh karakteristik lingkungan (faktor internal dan eksternal) yang menjadi penunjang efektivitas organisasi Sekretariat KPU Kabupaten Kepulauan pada Pemilu Legislatif Tahun 2014. dengan memanfaatkan faktor penunjang tersebut, maka terbentuklah organisasi 
yang efektif dalam tubuh Sekretariat KPU Kabupaten Kepulauan Meranti.

\section{Karakteristik Pekerja}

Melalui keterangan dari informan dan informasi data yang berhasil peneliti dapatkan selama penelitian, rincian komposisi pegawai Sekretariat KPU Kabupaten Kepulauan Meranti berdasarkan kualifikasi pendidikan dapat dilihat pada tabel di bawah berikut:

Tabel : 5.3

Rekapitulasi PNS Berdasarkan kualifikasi Pendidikan di Sekretariat KPU Kabupaten Kepulauan Meranti pada Pemilu Legislatif Tahun 2014

\begin{tabular}{|c|c|c|c|c|c|c|c|c|c|c|c|c|}
\hline \multirow[t]{2}{*}{ NO } & \multirow[t]{2}{*}{ URAIAN } & \multirow[t]{2}{*}{ JUMLAH } & \multicolumn{9}{|c|}{ PENDIDIKAN } & \multirow[t]{2}{*}{ KET } \\
\hline & & & S3 & S2 & S1 & D4 & D3 & D1 & SLTA & SLTP & SD & \\
\hline 1 & 2 & 3 & 4 & 5 & 6 & 7 & 8 & 9 & 10 & 11 & 12 & 13 \\
\hline 1 & SEKRETARIS & 1 & & 1 & & & & & & & & \\
\hline 2 & $\begin{array}{l}\text { Program dan } \\
\text { Data }\end{array}$ & 2 & & & 1 & 1 & & & & & & \\
\hline 3 & $\begin{array}{l}\text { Subbagian } \\
\text { Hukum }\end{array}$ & 2 & & & 2 & & & & & & & \\
\hline 4 & $\begin{array}{l}\text { Subbagian } \\
\text { Teknis dan } \\
\text { Hubungan } \\
\text { Partisipasi } \\
\text { Masyarakat }\end{array}$ & 2 & & & 2 & & & & & & & \\
\hline 5 & $\begin{array}{l}\text { Keuangan, } \\
\text { Umum dan } \\
\text { Logistik. }\end{array}$ & 4 & & & 3 & & & & 1 & & & \\
\hline \multicolumn{2}{|c|}{ JUMLAH } & 11 & 0 & 1 & 8 & 1 & 0 & 0 & 1 & 0 & 0 & \\
\hline
\end{tabular}

Sumber : Dokumen Sekretariat Komisi

Pemilihan Kabupaten Kepulauan Meranti

Kemudian dari latar belakang pengalaman masing-masing unsur Sekretariat Komisi Pemilihan Umum Kabupaten Kepulauan Meranti pada Pemilu Legislatif Tahun 2014, di peroleh informasi bahwa sekretaris KPU
Kabupaten

Kepulauan

Meranti merupakan mantan Kepala sekolah yang tentunya telah berpeengalaman dalam memimpin suatu organisasi. Sedangkan latar belakang masing-masing kepala subbagian merupakan mantan Guru sekolah dan satu orang kasubbag merupakan pegawai yang telah lama bertugas dan berpengalaman sebagai 
pegawai struktural di lingkungan Kabupaten Kepulauan Meranti.

Selanjutnya dari penelusuran peneliti mengenai latar belakang untuk pegawai negeri sipil dari unsur pegawai organik rekrutan KPU. Diperoleh informasi penting bahwa latar belakang pengalaman dari pegawai unsur sekretariat KPU pada Pemilu Legislatif Tahun 2014 merupakan individu yang telah berpengalaman dalam dunia kerja yakni dua orang PNS sekretariat unsur organik telah berpengalaman bekerja di bidang perbankan dan satu orang berpengalaman bekerja di organisasi kemanusian serta dua orang lainnya telah berpengalaman bekerja sebagai pegawai honorer.

Berdasarkan komposisi keseluruhan individu di dalam Sekretariat KPU Kabupaten Kepulauan Meranti tersebut di atas. Karakteristik pekerja yang dimiliki oleh Sekretariat KPU Kabupaten Kepulauan Meranti pada Pemilu Legislatif Tahun 2014, mempunyai pengaruh penting dan menjadi faktor penunjang dalam pelaksanaan seluruh tahapan dan kegiatan Pemilu Legislatif Tahun 2014.

\section{Praktek Manajemen}

Dalam sebuah organisasi manajer memainkan peranan sentral dalam keberhasilan suatu organisasi melalui perencanaan, koordinasi dan memperlancar kegiatan yang ditujukan ke arah sasaran. Kebijakan yang baik adalah kebijakan tersebut secara jelas membawa kita ke arah tujuan yang diinginkan. Pada intinya manajemen adalah tentang memutuskan apa yang harus dilakukan kemudian melaksanakannya melalui sumber daya manusia yang ada.

Pada saat pelaksanaan tahapan dan kegiatan Pemilu Legislatif Tahun 2014, Sekretariat KPU Kabupaten Kepulauan Meranti membentuk struktur pelaksana dan penanggung jawab setiap kegiatan/program agar seluruh tahapan dan kegiatan Pemilu terlaksana dengan baik sesuai dengan jadwal dan tahapan yang telah ditetapkan. Adanya struktur tentu akan membantu atau terprogramnya sistem kerja yang dilaksanakan oleh Sekretariat KPU Kabupaten Kepulauan Meranti pada penyelenggaraan Pemilu Legislatif Tahun 2014 di Kabupaten Kepulauan Meranti.

Di dalam struktur dan tata pembagian kerja merupakan garis komando dari Pimpinan, manfaatnya dapat memperjelas garis koordinasi atau perintah, dan menghindari overlapping dalam pekerjaan. Dari pembagian dalam 
struktur tentu akan dapat memperoleh informasi yang lengkap dan jelas agar tidak terjadinya ketimpang tindihan dalam melaksanakan tugas dan struktur atau pembagian tata kerja yang dapat menimbulkan adanya rasa tanggung jawab dalam pekerjaan karena telah mengetahui bidang dan fungsinya masing-masing.

Namun meski telah terbentuk struktur pelaksana dan penanggung jawab suatu kegiatan, Sekretaris KPU Kabupaten Kepulauan Meranti lebih menekankan pola "tugas dan tanggung jawab bersama" dalam mengatasi segala kendala dalam pelaksanaan kegiatan tahapan Pemilu Legislatif Tahun 2014. Ketika pekerjaan membutuhkan konsentrasi yang besar, maka sekretaris, kasubbag beserta staf turun bersamasama menanganinya. Masalah salah satu subbagian dijadikan sebagai masalah bersama, dicarikan solusi untuk penanganan masalah tersebut secara komprehensif.

Dan menariknya dalam hal pelaksanaan kegiatan pada Pemilu Legislatif Tahun 2014 di KPU Kabupaten Kepulauan Meranti, berdasarkan hasil wawancara dengan informan Nurhayati dan Loli Sastra ( staf KPU Kab. Kepulauan Meranti) diperoleh fakta lainnya mengenai cara kerja/manajemen sekretariat KPU Kabupaten Kepulauan Meranti pada Pemilu Legislatif Tahun 2014. Melalui kutipan wawancara dengan kedua informan tersebut, diperoleh informasi penting bahwa:

Kami seluruh staf PNS sekretariat KPU Kabupaten Kepulauan Meranti, selalu bekerjasama dan saling membantu dalam melaksanakan seluruh tahapan dan kegiatan Pemilu Legislatif Tahun 2014.

Dari keterangan yang disampaikan oleh informan di atas, diperoleh fakta penting bahwa meski dalam pelaksanaan kegiatan/program tahapan Pemilu Legislatif Tahun 2014 telah dibentuk struktur pelaksana dan penanggung jawab kegiatan/program tersebut. Namun keseluruhan unsur PNS Sekretariat KPU Kabupaten Kepulauan Meranti tetap terlibat dan membantu keseluruhan program/kegiatan tahapan Pemilu Legislatif Tahun 2014 meski namanya tidak tercantum dalam struktur sebagai pelaksana atau penanggung jawab dalam kegiatan/program tersebut.

Mengenai hal tersebut di atas, menjelaskan bahwa efektivitas organisasi pada dasarnya dideterminasi juga oleh faktor leadership dan pola 
manajemen yang dipergunakan. Pola manjemen yang di lakukan oleh Sekretariat KPU Kabupaten Kepulauan Meranti Pada Pemilu Legislatif Tahun 2014 berdasarkan keterangan informan di atas, mengarah pada pola Human Relation, yakni lebih menekankan pada elemen emosional, tidak berencana, serta non rasional di dalam perilaku organisasi. Temuan dari penelitian ini memperlihatkan kuatnya penggunaan pola ini oleh Sekretariat KPU Kabupaten Kepulauan Meranti pada Pemilu Legislatif Tahun 2014.

Dengan menggunakan pola manaemen kedekatan secara emosional kemanusian dalam manajemen organisasi sekretariat KPU Kabupaten Kepulauan Meranti pada Pemilu Legislatif Tahun 2014, maka seluruh kegiatan pelaksanaan tahapan Pemilu dapat terlaksana dengan baik.

Dari hasil keseluruhan pendalaman terhadap 4 (empat) faktor yang menunjang efektitas organisasi yakni karakterisk organisasi, karakteristik lingkungan, karakteristik pekerja dan pengelolaan manajemen. Penggunaan sescara maksimal keempat faktor penunjang organisasi tersebut di dalam tubuh Sekretariat KPU Kabupaten Kepulauan Meranti pada Pemilu Legislatif Tahun 2014, menjadi aspek penting yang menentukan keberhasilan kinerja Sekretariat KPU Kabupaten Kepulauan Meranti dalam melaksanakan penyelenggaraan Pemilu Legislatif Tahun 2014 sesuai dengan program/kegiatan dan jadwal yang telah ditetapkan. Sehingga dalam hal ini Sekretariat KPU Kabupaten Kepulauan Meranti pada Pemilu Legislatif Tahun 2014 menjadi organisasi yang efektif.

Selanjutnya berkat kinerja dan efektifnya organisasi Sekretariat KPU Kabupaten Kepulauan Meranti pada Pemilu Legislatif Tahun 2014 lalu, KPU Provinsi Riau mengapresiasi dengan memberikan penghargaan sebagai penyelenggara Pemilu berprestasi ketiga tingkat KPU Kabupaten/Kota pada penyelenggaraan Pemilu Tahun 2014.

\section{Kesimpulan}

Melalui penelitan tentang Faktorfaktor yang mempengaruhi Efektivitas Organisasi Sekretariat KPU Kabupaten Kepulauan Meranti pada Pemilu Legislatif Tahun 2014 dapat disimpulkan hal sebagai berikut:

1. Bahwa situasi pergantian ataupun kekosongan komisioner KPU Kabupaten Kepulauan Meranti pada saat pelaksanaan Tahapan Pemilu Legislatif Tahun 2014 tidak menjadi kendala bagi Sekretariat KPU 
Kabupaten Kepulauan Meranti dalam rangka menjalankan tugas dan fungsinya sebagai salah satu unsur penyelenggara Pemilu.

2. Dengan karakteristik organisasi yang solid, karakteristik lingkungan yang kondusif, karakteristik pekerja yang berpengalaman dalam organisasi, serta praktek manajemen dengan pola human relations yang dijalankan oleh Sekretariat KPU Kabupaten Kepulauan Meranti pada Pemilu Legislatif Tahun 2014. Maka segala tantangan dan kendala pada pelaksanaan tahapan dan kegiatan Pemilu Legislatif Tahun 2014 dapat diatasi dengan baik.

3. Efektifnya organisasi Sekretariat KPU Kabupaten Kepulauan Meranti pada Pemilu Legislatif Tahun 2014, menepis pendapat beberapa kalangan yang meragukan integritas penyelenggara Pemilu dari unsur pemerintah. Karena sebagaimana diketahui bahwa sekretariat KPU di isi oleh pegawai yang berasal dari unsur pemerintah.

\section{Saran}

Melalui penelitian ini, dalam mengadapi situasi pergantian ataupun kekosongan komisioner pada saat pelaksanaan tahapan dan kegiatan Pemilu sedang berlangsung seperti yang dialami oleh KPU Kabupaten Kepulauan Meranti pada Pemilu Legsilatif Tahun 2014, maka peneliti menyarankan hal sebagai berikut:

1. Penguatan organisasi sekretariat, yakni dengan menjalin komunikasi yang baik dan intens di dalam lingkungan sekretariat. Sehingga terangkum seluruh informasi mengenai gagasan, ataupun kendala yang dihadapi oleh sekretariat dalam pelaksanaan tahapan Pemilu.

2. Pemanfaatan segala sumber daya yang dimiliki oleh sekretariat secara maksimal. Dalam hal tenaga (Sumber Daya Manusia) yaitu dengan menempatkan secara tepat pekerja yang profesional dan berpengalaman di dalam organisasinya. Serta memanfaatkan segala sarana dan prasarana yang ada, dalam kondisi terkini saat ini yaitu sarana teknologi.

3. Menerapkan pola manajemen yang menimbulkan semangat bekerja, kesadaran berkerja serta tanggung jawab bersama dalam berkerja pada organisasi Sekretariat. Pola manajemen tersebut dapat dilakukan melalui hubungan 


\author{
kedekatan secara emosional dalam \\ organisasi Sekretariat.
}

\section{Daftar Pustaka}

Andrew Ellis, et al., Engaging the Electorate Inhabitants to Promote Voter Turnout from Around the World, (Stockholm: International IDEA, 2006).

Afrizal. 2014. Metode Penelitian Kualitatif. Jakarta: Raja Grafindo.

Cresweel, John W. 2015. Penelitian Kualitatif dan Desain Riset: Memilih di Antara Lima Pendekatan. Penerjemah: Ahmad Lintang Lazuardi. Yogyakarta: Pustaka Pelajar.

Etzioni, Amitai. 1982. Organisasi-Organisasi Modern, Alih bahasa oleh Suryatim. Jakarta: Universias Indonesia dan Pustaka Brajaguna.

Fachrudin Lauma (2015), Kualitas KPU Kota Manado Sebagai Penyelenggara Pemilihan Walikota Dan Wakil Walikota Manado Tahun 2015, Jornal Polico: Ilmu Politik, Vol, 6, No.1, UNSRAT.

Gibson, et al, 1995. Organisasi dan Manajemen, Edisi ke empat, Jakarta : Erlangga,

Hardjito, Dydiet. (2001). Teori Organisasi dan Teknik Pengorganisasian. Jakarta: Pt. Raja Grafindo Persada.

J. Salusu. 2006. Pengambilan Keputusan Strategik Untuk Organisasi Publik dan Organisasi Non Profit. Grasindo. Jakarta.

Moleong, Lexy.(2005). Metode Penelitian Kualitatif. Bandung: PT Rosdakarya.

Siagian, Sondang P., 1995. Teori Perkembangan Organisasi. Jakarta: Bumi Aksara.
Steers, M Richard. (1985). Efektivitas Organisasi Perusahaan. Jakarta: Erlangga.

Sugiyono. 2011. Metode Penelitian Kuantitatif, Kualitatif dan R\&D, , Bandung: Alfabeta.

Surbakti, Ramlan, dkk.2011. Menjaga Integritas Pemungutan dan Penghitungan Suara, Seri Demokrasi Elektoral:Buku 13. Jakarta: Kemitraan bagi Pembaruan Tata Pemerintahan.

Surbakti, Ramlan, Kris Nugroho. 2015. Studi Desain Kelembagaan Pemilu yang Efektif. Jakarta: Kemitraan bagi Pembaharuan Tata Pemerintahan Indonesia.

Yuniarsih Tjutju dan Suwatno. 2008. Manajemen Sumber Daya Manusia. Bandung: Alfabeta.

\section{Peraturan Perundang-undangan:}

Undang-Undang Nomor 7 Tahun 2017 tentang Pemilihan Umum

Undang-Undang Nomor 15 Tahun 2011 tentang Penyelenggara Pemilihan Umum.

Peraturan KPU Nomor 07 Tahun 2012 tentang Tahapan, Program, dan Jadwal Penyelenggaraan Pemilihan Umum Anggota Dewan Perwakilan Rakyat, Dewan Perwakilan Daerah, dan Dewan Perwakilan Rakyat Daerah.

Peraturan Komisi Pemilihan Umum Nomor 06 Tahun 2008 tentang Susunan Organisasi dan Tata Kerja Sekretariat Jenderal Komisi Pemilihan Umum, Sekretariat Komisi Pemilihan Umum Provinsi, Sekretariat Komisi Pemilihan Umum Kabupaten/Kota.

\section{Website :}

https://mediaindonesia.com/read/detail/21386 9-jelang-pemilu-2019-komisioner-kpuntt-masih-kosong 
https://cakrawala.co/kpu-gorut-kekosongandua-komisioner-tidak-menggangutahapan-pilkada/

http://mediaindonesia.com/read/detail/21386 9-jelang-pemilu-2019-komisioner-kpuntt-masih-kosong \& https://kaltimtoday.co/utama/kaltim/ko misioner-kpu-kaltim-kosong-kpu-riambil-alih.

www.kpu.go.id 